\title{
Modulation of the expression of folate cycle enzymes and polyamine metabolism by berberine in cisplatin- sensitive and -resistant human ovarian cancer cells
}

\author{
GAETANO MARVERTI ${ }^{1}$, ALESSIO LIGABUE ${ }^{1}$, PAOLO LOMBARDI ${ }^{3}$, STEFANIA FERRARI $^{2}$, \\ MARIA GIUSEPPINA MONTI ${ }^{1}$, CHIARA FRASSINETI ${ }^{1}$ and MARIA PAOLA COSTI ${ }^{2}$ \\ Departments of ${ }^{1}$ Biomedical Sciences, Metabolic and Neuroscience, Section of Pharmacology \\ and Molecular Medicine and ${ }^{2}$ Life Sciences, University of Modena and Reggio Emilia, \\ I-41125 Modena; ${ }^{3}$ Naxospharma Srl, I-20026 Novate Milanese, Italy
}

Received April 15, 2013; Accepted May 30, 2013

DOI: 10.3892/ijo.2013.2045

\begin{abstract}
Berberine is a natural isoquinoline alkaloid with significant antitumor activity against many types of cancer cells, including ovarian tumors. This study investigated the molecular mechanisms by which berberine differently affects cell growth of cisplatin (cDDP)-sensitive and -resistant and polyamine analogue cross-resistant human ovarian cancer cells. The results show that berberine suppresses the growth of cDDP-resistant cells more than the sensitive counterparts, by interfering with the expression of folate cycle enzymes, dihydrofolate reductase (DHFR) and thymidylate synthase (TS). In addition, the impairment of the folate cycle also seems partly ascribable to a reduced accumulation of folate, a vitamin which plays an essential role in the biosynthesis of nucleic acids and amino acids. This effect was observed in both lines, but especially in the resistant cells, correlating again with the reduced tolerance to this isoquinoline alkaloid. The data also indicate that berberine inhibits cellular growth by affecting polyamine metabolism, in particular through the upregulation of the key catabolic enzyme, spermidine/spermine $N 1$-acetyltransferase (SSAT). In this regard, berberine is shown to stimulate the
\end{abstract}

Correspondence to: Professor Gaetano Marverti, Department of Biomedical Sciences, Metabolic and Neuroscience, Section of Pharmacology and Molecular Medicine, Via Campi 287, I-41125 Modena, Italy

E-mail: gaetano.marverti@unimore.it

Abbreviations: cDDP, cisplatin or cis-diamminedichloroplatinum; Put, putrescine; Spd, spermidine; Spm, spermine; SSAT, spermidine/ spermine N1-acetyltransferase; BESpm, N1,N12-bisethylspermine; DENSpm, N1,N11-diethylnorspermine; DHFR, dihydrofolate reductase; TS, thymidylate synthase; 5-FU, 5-fluorouracil; MTX, methotrexate; $\mathrm{CH}_{2} \mathrm{FH}_{4}, 5,10$-methylenetetrahydrofolate; $\mathrm{FH}_{4}$, tetrahydrofolate

Key words: berberine, polyamines, spermidine/spermine N1-acetyltransferase, cisplatin-resistance, thymidylate synthase, dihydrofolate reductase
SSAT induction by the spermine analogue N1, N12 bisethylspermine (BESpm), which alone was also able to downregulate DHFR mRNA more than TS mRNA. We report that the sensitivity of resistant cells to cisplatin or to BESpm is reverted to the levels of sensitive cells by the co-treatment with berberine. These data confirm the intimate inter-relationships between folate cycle and polyamine pathways and suggest that this isoquinoline plant alkaloid could be a useful adjuvant therapeutic agent in the treatment of ovarian carcinoma.

\section{Introduction}

Ovarian cancer is the most lethal gynecological cancer in industrialized countries and is the fifth leading cause of cancer deaths in women. Ovarian carcinoma becomes often resistant to conventional systemic therapies even after the first treatments and the prognosis for patients with advanced ovarian cancer remains poor (1).

The standard first-line treatment for ovarian cancer is a combination of paclitaxel and a Pt derivative drug such as cisplatin (cDDP) or carboplatin alone (2).

cDDP and its derivatives have been widely used to treat a variety of solid tumors including testicular, ovarian, head and cervical carcinoma (3). However, the appearance of resistant cells in the tumor limits its therapeutic effectiveness, thus cDDP is usually administered in combination with other drugs (4), lowering of drug dosages and consequently decrease side-effects, reducing the opportunity for the development of drug resistance by cancer cells (5).

Acquired resistance to cDDP and its derivatives is a multifactorial process involving many mechanisms, among these enhanced DNA synthesis and repair is the most common feature of resistance in almost all resistant cell lines studied. In this context, the overexpression of folate cycle enzymes dihydrofolate reductase (DHFR) and thymidylate synthase (TS) played an important role in a large survey of cDDP resistance human ovarian carcinoma cell lines (6). Therefore, the discovery of drugs aimed at impairing the activity of these enzymes, thus circumventing cDDP-resistance, is of great interest. 
However, even chemotherapy based on combination of drugs is associated with significant side-effects, highlighting the need for therapeutic strategies that target tumor cells without compromising normal tissue function (7). Thus, the development of novel systemic agents from natural products with low toxicity and few side-effects is being actively pursued $(8,9)$.

In this regard, cDDP has been recently combined with berberine, obtaining enhanced apoptotic cell death through a mitochondria/caspase-mediated pathway in HeLa cells (10).

Berberine is an isoquinoline alkaloid (Fig. 1) isolated from a variety of Chinese herbs, including Coptidis rhizoma, Phellodendron chinense schneid and Phellodendron amurense and other important medicinal plant species such as Berberis aristata and Berberis aquifolium and has diverse pharmacological actions such as antibacterial $(11,12)$ and anti-inflammatory (13). The antineoplastic activities of berberine have been demonstrated against a variety of human cancer cells both in vitro and in vivo through suppression of tumor cell proliferation, or induction of tumor cell apoptosis $(14,15)$. The pharmacologic effects depend on inhibition of DNA and protein synthesis, arrest of cell cycle progression $(16,17)$. Besides, it has been reported that berberine has dual topoisomerase I and II poisoning activity and binds to double helical DNA with high affinity. Other potential targets of berberine hydrochloride include reactive oxygen species generation, mitochondrial function, RNA binding, the estrogen receptor, matrix metalloproteinase regulation and p53 activation (18-20). Nevertheless, it is relatively nontoxic to humans (21).

We have recently reported (22), that the binding at the AT-rich sequences of the minor groove of double-strand DNA of the natural antibiotic distamycin $(23,24)$ was accompanied by the downregulation of both dihydrofolate reductase (DHFR) and thymidylate synthase (TS) in cisplatin-sensitive and -resistant cell lines.

TS catalyzes the reductive methylation of dUMP by $\mathrm{CH}_{2} \mathrm{H}_{4}$ PteGlu, generating dTMP and dihydrofolate (25). DHFR catalyzes the reduction of folate and 7,8-dihydrofolate (DHF) to 5,6,7,8-tetrahydrofolate (THF), utilizing NADPH as cofactor. Both reactions are essential steps in the biosynthesis of nucleotidic bases of DNA and thus important targets for chemotherapy (26).

Increasing body of evidence has suggested intimate interrelationships between folate cycle and polyamine pathways, since the polyamine key catabolic enzyme spermidine/ spermine N1-acetyl transferase (SSAT; EC 2.3.1.57) was identified as being one of the most affected genes in studies based on folate cycle inhibitors such as 5-FU (27-29). The polyamine pathway is an attractive target in the development of anticancer strategies (30), since the naturally occurring polyamines putrescine (Put), spermidine (Spd) and spermine (Spm) are essential for cell growth and differentiation and present elevated concentrations in cancer cells (31). In this regard, we have also reported that combinations of novel folate cycle inhibitors with quinoxaline structure and drugs that specifically target polyamine metabolism, such as diethylderivatives of norspermine (DENSPM) or spermine (BESpm), have synergistic effect in killing cisplatin-sensitive and drugresistant daughter human ovarian cell lines (29). Besides, we have previously indicated the limited induction of SSAT activity as an important determinant of the reduced response to BESpm in the cDDP-resistant human ovarian cancer $\mathrm{C} 13^{*}$ cells (32).

In the present study, we investigated the effects of berberine on cDDP-sensitive human ovarian cancer cells and, for the first time, on the resistant counterparts and examined the functional role of folate cycle enzymes and polyamine metabolism in berberine-induced cell growth inhibition. Besides, in this study the relationship between berberine-induced cell death and TS, DHFR and SSAT expression was explored, as well as the nature of the interaction between berberine with either cDDP or a polyamine analogue against ovarian carcinoma cell models.

\section{Materials and methods}

Chemical reagents. Berberine was provided by Dr P. Lombardi, Naxospharma (Milan, Italy) and was freshly dissolved in DMSO prior to addition to cell cultures. Cells treated with vehicle only [DMSO, maximum concentration, $0.5 \%(\mathrm{v} / \mathrm{v})$ in media] served as control. $\left[5-{ }^{3} \mathrm{H}\right] \mathrm{dUMP}(20 \mathrm{Ci} / \mathrm{mmol})$, was purchased from Moravek Biochemicals (Brea, CA, USA). BESpm was kindly supplied by Hoechst Marion Roussel Inc. (Cincinnati, OH, USA). 1-[ $\left.{ }^{14} \mathrm{C}\right]$ acetyl coenzyme (1.89 GBq/ mmol) was purchased from Perkin-Elmer Italia (Milan, Italy). All other chemicals were purchased from Sigma-Aldrich S.r.l. (Milan, Italy), except when otherwise indicated.

Cell lines. The 2008 cell line was established from a patient with advanced cystadenocarcinoma of the ovary. The cDDPresistant $\mathrm{C}_{13} *$ subline, which is $\sim 15$-fold resistant to cDDP, was derived from the parent 2008 cell line by monthly exposure to cDDP, followed by chronic exposure to step-wise increases in cDDP concentration (33). The cell lines were grown in monolayers in RPMI-1640 medium containing 10\% heatinactivated foetal bovine serum and $50 \mu \mathrm{g} / \mathrm{ml}$ gentamycin sulphate. Vero cells, established from kidney cells of the African green monkey (Cercopithecus aethiops) and obtained from the Istituto Zooprofilattico (Brescia, Italy), were chosen as a control cell line (34). All cell media and serum were purchased from Lonza (Verviers, Belgium). Cultures were equilibrated with humidified $5 \% \mathrm{CO}_{2}$ in air at $37^{\circ} \mathrm{C}$. All studies were performed in mycoplasma-negative cells, as routinely determined using the MycoAlert Mycoplasma detection kit (Lonza, Walkersville, MD, USA). Protein content in the assays was estimated using the Lowry method (35), unless otherwise indicated.

Cell growth assay. Cell growth was determined using a modified crystal violet assay (36). On selected days, the tissue culture medium was removed and the cell monolayer fixed with methanol and stained with $0.2 \%$ crystal violet solution in $20 \%$ methanol for at least $30 \mathrm{~min}$. After being washed several times with distilled water to remove excess dye, the cells were left to dry. The incorporated dye was solubilised in acidified isopropanol (1 N HCl:2-propanol, 1:10). After appropriate dilution, absorbance was determined spectrophotometrically at $540 \mathrm{~nm}$. The extracted dye was proportional to the cell number. The percentage of cytotoxicity was calculated by 


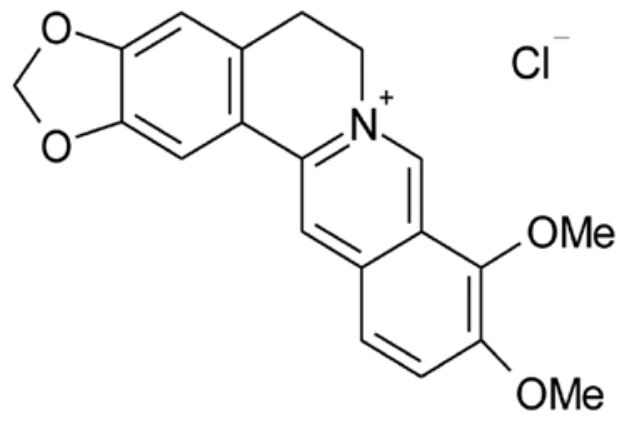

Figure 1. Chemical structure of berberine.

comparing the absorbance of cultures exposed to the drug to unexposed (control) cultures.

TS catalytic assay. Cells used for the enzyme assay were harvested by trypsinisation in an exponential growth phase, washed with PBS and used or stored at $-20^{\circ} \mathrm{C}$. Cell pellets were thawed by the addition of ice-cold lysis buffer $(200 \mathrm{mM}$ Tris-HCl, pH 7.4, 20 mM 2-mercaptoethanol, $100 \mathrm{mM} \mathrm{NaF}$ and $1 \%$ Triton $\mathrm{X}-100$ ), sonicated (three $\mathrm{x} 5 \mathrm{sec}$ ) and subsequently centrifuged at $14,000 \mathrm{x} \mathrm{g}$ for $15 \mathrm{~min}$ at $4^{\circ} \mathrm{C}$. The supernatant was used for enzyme assays. The TS catalytic assay was conducted according to a previously reported method (37); the assay determined the catalytic activity of TS by measuring the amounts of ${ }^{3} \mathrm{H}$ released during the TS catalyzed conversion of $\left[5-{ }^{3} \mathrm{H}\right] \mathrm{dUMP}$ to dTMP. Briefly, the assay consisted of the enzymes in assay buffer (lysis buffer without Triton X-100) and $650 \mu \mathrm{M} 5,10$-methylenetetrahydrofolate in a final volume of $50 \mu \mathrm{l}$. The reaction was started by adding $\left[5-{ }^{3} \mathrm{H}\right] \mathrm{dUMP}(1 \mu \mathrm{M}$ final concentration, specific activity $5 \mathrm{mCi} / \mathrm{mol}$ ), followed by incubation at $37^{\circ} \mathrm{C}$ for $60 \mathrm{~min}$ and stopped by adding $50 \mu \mathrm{l}$ of ice-cold $35 \%$ trichloroacetic acid. Residual $\left[5-{ }^{3} \mathrm{H}\right] \mathrm{dUMP}$ was removed by adding $250 \mu \mathrm{l}$ of $10 \%$ neutral activated charcoal. The charcoal was removed by centrifugation at $14,000 \mathrm{x} \mathrm{g}$ for $15 \mathrm{~min}$ at $4^{\circ} \mathrm{C}$ and a $150-\mu l$ sample of the supernatant was assayed for tritium radioactivity by liquid scintillation counting in the liquid scintillation analyzer Tri-Carb 2100 (Packard). For each cell line, the linearity of $\left[5-{ }^{3} \mathrm{H}\right] \mathrm{dUMP}$ conversion with respect to amount of protein and time was established.

DHFR catalytic assay. DHFR activity, measured as folate reductase, was determined by the $\left[{ }^{3} \mathrm{H}\right]$-folate reductase assay, as previously described (38). Briefly, cells were harvested by trypsinization in an exponential growth phase, washed with PBS buffer and resuspended in $60 \mathrm{mM}$ sodium citrate, pH 7.2 containing $10 \mathrm{mM}$ 2-mercaptoethanol. Cell lysate was prepared by freeze thawing three times. The insoluble debris was removed by centrifugation at $14,000 \times \mathrm{g}$ for $15 \mathrm{~min}$ at $4^{\circ} \mathrm{C}$. The supernatant was used immediately for enzyme assay after the determination of protein concentration by the method of Bradford, using the Bio-Rad reagent with bovine serum albumin as a standard (39). $\left[{ }^{3} \mathrm{H}\right]$-folate $(25 \mathrm{pmol})$ was preincubated with $1.5 \mu \mathrm{mol}$ of dithionite for $10 \mathrm{~min}$ at $37^{\circ} \mathrm{C}$ in a total volume of $250 \mu \mathrm{l}$. Following this incubation $60 \mathrm{nmol}$ of NADPH and the enzyme preparation were added together with an appropriate amount of sodium citrate buffer $\mathrm{pH} 7.2$ to reach a final volume of $500 \mu$ l. The reaction was performed for $60 \mathrm{~min}$ at $37^{\circ} \mathrm{C}$ and stopped by adding, in sequence, $200 \mu \mathrm{l}$ of a solution $0.027 \mathrm{M}$ folic acid, $100 \mu \mathrm{l}$ of $0.1 \mathrm{~N} \mathrm{HCl}$ and $200 \mu \mathrm{l}$ of $0.3 \mathrm{~N}$ zinc sulfate. The yellow folate precipitate was pelletted by centrifugation at $16,000 \mathrm{x} \mathrm{g}$ for $45 \mathrm{~min}$ and the tritium radioactivity of the supernatant was measured by adding $500 \mu 1$ to $10 \mathrm{ml}$ of Emulsifier Scintillation Plus cocktail (Perkin-Elmer Italia) in the liquid scintillator analyzer Tri-Carb 2100 (Packard). For each cell line, linearity of $\left[{ }^{3} \mathrm{H}\right]$-folate conversion with respect to the amount of protein and time was established.

Western blotting. Cells were harvested, washed twice in ice-cold 1X PBS and resuspended in a buffer consisting of $20 \mathrm{mM}$ Tris- $\mathrm{HCl}$ (pH 7.4), $150 \mathrm{mM} \mathrm{NaCl}, 1 \mathrm{mM}$ EDTA (pH 8.0), $1 \%$ Triton X-100 and $0.1 \%$ SDS. Cells were lysed by freeze-thaw three times followed by sonication using three 2 - to -3-sec bursts. The insoluble debris was removed by centrifugation at $15,000 \mathrm{x}$ g for $30 \mathrm{~min}$. Protein concentrations were determined using the Lowry method (35). Each protein sample $(25 \mu \mathrm{g})$ was resolved by SDS-PAGE (12\%). The gels were electroblotted onto hydrophobic polyvinylidene difluoride membranes (Hybond ${ }^{\mathrm{TM}}$-P PVDF, GE Healthcare Bio-Science, Uppsala, Sweden). Antibody staining was performed with a chemiluminescence detection system (ECL Plus Western Blotting Detection Reagent, GE Healthcare Bio-Science), using a 1:500 dilution of the mouse anti-human TS (TS106) monoclonal primary antibody (Invitrogen S.r.l., Milan, Italy), 1:1,000 dilutions of the mouse anti-human DHFR monoclonal antibody (Tebu-Bio, Milan, Italy) and 1:1,000 of mouse anti-human $\beta$-tubulin antibody (SigmaAldrich) in conjunction with a 1:3,000 dilution of horseradish peroxidase-conjugated sheep anti-mouse secondary antibody (GE Healthcare Bio-Science). Quantification of signal intensity was performed by densitometry on a GS-800 calibrated densitometer (Bio-Rad) and analysed by using Quantity One software (Bio-Rad, CA, USA).

Real-time reverse transcription-PCR analysis. Total RNA was extracted from the cultured cells using TRI reagent (SigmaAldrich). Reverse transcription was performed with $2 \mu \mathrm{g}$ of total RNA using random primers (Promega, Milan, Italy) and M-MLV reverse transcriptase (Promega). Real-time RT-PCR was performed with $10 \mathrm{ng}$ of cDNA using Power SYBR ${ }^{\circledR}$ Green PCR Master Mix [Applied Biosystems, Monza (MI), Italy] and an ABI-PRISM 7900 HT Sequence Detection System (SDS, Applied Biosystems), followed by a dissociation curve analysis and subsequent agarose gel electrophoresis to confirm amplification. The following primer sets were used: TS [NCBI reference sequence: NM_001071.1], forward: 5'-CAG ATTATTCAGGACAGGGAGTT-3', reverse: 5'-CATCAGAG GAAGATCTCTTGGATT-3'; DHFR [NCBI reference sequence: NM_000791.3], forward: 5'-TGCACAAATG GGGACGA-3', reverse: 5'-GGAAATATCTGAATTCAT TCCTGAG-3'; and GAPDH [NCBI reference sequence: NM_002046.3], forward: 5'-CAAGGTCATCCATGACAA CTTTG-3', reverse: 5'-GGGCCATCCACAGTCTTCTG-3'. SSAT primer sequences were, forward: 5'-TTATAGAGGCT TTGGCATAGGA-3', reverse: 5'-TCATTGCAACCTGGCT TAGA-3'. The amount of target, normalised to an endogenous reference (glyceraldehydes-3-phosphate dehydrogenase, 
A

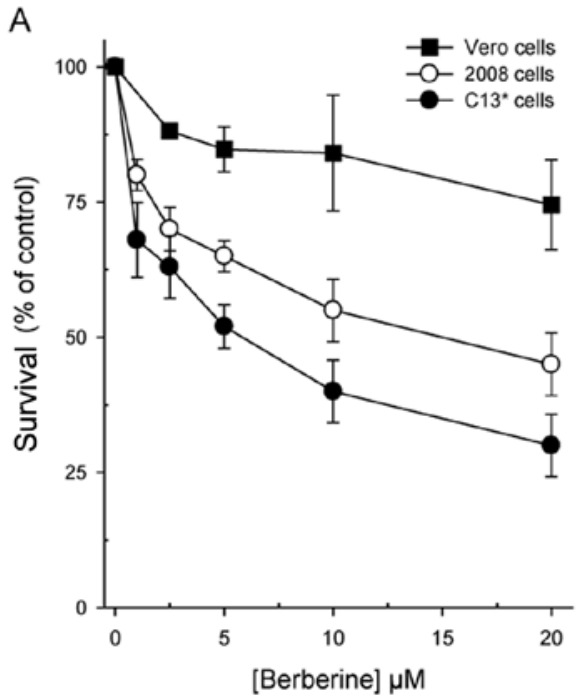

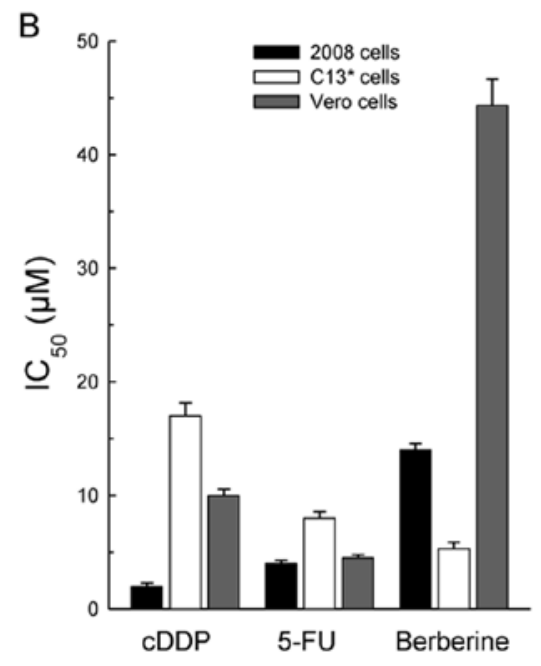

Figure 2. Cell growth inhibition by berberine. The dose-response curve of berberine (A) and the comparison of the $\mathrm{IC}_{50}$ values ( $\left.\mu \mathrm{M}\right)$ for $\mathrm{cDDP}, 5-\mathrm{FU}$ and berberine in 2008, $\mathrm{C13}^{*}$ and Vero cell lines (B) were determined after a 3-day exposure to the drugs. Results represent the mean of five separate experiments performed in duplicate. Error bars, SEM. The $\mathrm{IC}_{50}$ is defined as the concentration causing $50 \%$ growth inhibition in treated cells when compared to control.

GAPDH) and relative to a calibrator (2008 cell line or untreated sample), was given by $2^{-\Delta \Delta C t}$ calculation (40). All experiments were carried out three times in triplicate; amplification plots were analysed using the ABI-PRISM 7900 HT SDS version 2.1 software (Applied Biosystems).

$\left[{ }^{3} \mathrm{H}\right]$ folic acid uptake studies. $\left[{ }^{3} \mathrm{H}\right]$ folic acid uptake studies were performed according to previously published methods (41) with minor modifications. Briefly, one day after seeding, cells were treated for $72 \mathrm{~h}$ and then incubated for $10 \mathrm{~min}$ at $37^{\circ} \mathrm{C}$ with $50 \mathrm{nM}$ of $\left[{ }^{3} \mathrm{H}\right]$ folic acid, after a 20 -min acidic treatment with stripping buffer (acetate $\mathrm{pH} 4.0$ ) to remove endogenous folates bound to folate receptor (FR) at the cell surface. At the end of each experiment, cells were washed with $3 \mathrm{X} 1 \mathrm{ml}$ of ice-cold PBS pH 7.4, to arrest the reaction. The cells were then solubilised with $0.3 \mathrm{ml} 0.1 \%$ (v/v) Triton X-100 in $1 \% \mathrm{NaOH}$ and placed at $37^{\circ} \mathrm{C}$ overnight. An aliquot was transferred to scintillation vials containing $5 \mathrm{ml}$ of scintillation cocktail. Radioactivity associated with the cells was quantified using a scintillation counter (TriCarb 2100, Packard, USA) and the protein content of each sample measured by the method of Lowry using bovine serum albumin as the standard.

Assay of SSAT activity. SSAT activity was measured as previously described (42). The cells were harvested, washed twice in PBS and suspended in a buffer containing $10 \mathrm{mM}$ tris(hydroxymethyl)aminomethane $(\mathrm{pH}$ 7.2) and $1 \mathrm{mM}$ dithiothreitol. This suspension was freeze-thawed twice, then cytosolic aliquots were incubated in $100 \mathrm{mM}$ tris(hydroxymethyl)aminomethane ( $\mathrm{pH} \mathrm{8.0),} 3 \mathrm{mM}$ Spd and $0.5 \mathrm{nmol} 1-\left[{ }^{14} \mathrm{C}\right]$ acetyl coenzyme $\mathrm{A}$ in a final volume of $50 \mu \mathrm{l}$ for $10 \mathrm{~min}$ at $30^{\circ} \mathrm{C}$. The reaction was stopped by adding $10 \mu \mathrm{l}$ of $1 \mathrm{M} \mathrm{NH}_{2}-\mathrm{OH} \mathrm{HCl}$ and boiling in water for $3 \mathrm{~min}$. The resulting samples were spotted onto P-81 phosphocellulose discs and radioactivity measured by scintillation counting. The amount of cytosol added to the final reaction mixture was adjusted to maintain the enzyme/substrate concentrations within the linear range. Enzyme activity is expressed as pmol $\left[{ }^{14} \mathrm{C}\right]$ acetylspermidine formed $/ \mathrm{min} / \mathrm{mg}$ protein.

Synergy analysis. The nature of the interaction between berberine and cisplatin or the polyamine analogue, combined simultaneously at a fixed ratio based on the different cell sensitivity to each drug, was determined using median-effect analysis (43), with the CalcuSyn ver. 2.0 software (Biosoft, Cambridge, UK), which calculates a non-exclusive case combination index (CI) for every fraction affected (FA), a measure of the drug interaction effects. CI values of $<1$ or $>1$ indicated synergy and antagonism, respectively, whereas a CI value of 1 indicated additive effects of the drugs. Growth inhibition was assayed by the crystal violet dye assay to determine the doseresponse curves for each agent alone and in combination at a fixed ratio based on their $\mathrm{IC}_{50}$ values. Computer analysis of the dose-response curves was used to calculate the combination index (CI) at increasing levels of cell kill.

Statistical analysis. All values report the mean \pm SEM, unless otherwise indicated. Statistical significance was estimated by two-tailed Student's t-test performed using Microsoft Excel software; a difference was considered significant at $\mathrm{P}<0.05$ or $\mathrm{P}<0.01$.

\section{Results}

Effect of berberine on the growth of cDDP-sensitive and -resistant cell lines. The dose-response curves of berberine in the cDDP-sensitive and -resistant cell lines (2008 and C13*) and Vero cells, depicted in Fig. 2A reveal a collateral sensitivity of the cDDP-resistant line $\left(\mathrm{IC}_{50}=5.3 \pm 0.6 \mu \mathrm{M}\right.$ versus $\mathrm{IC}_{50}=14.5 \pm 1.2 \mu \mathrm{M}$ in $2008 \mathrm{cDDP}$-sensitive cells) to the drug. Collateral sensitivity is a phenomenon which describes a cell population that is resistant to certain drugs and is more sensitive to others. Berberine is also quite selective since it was much less cytotoxic against the non-tumorigenic Vero lineage. 
A
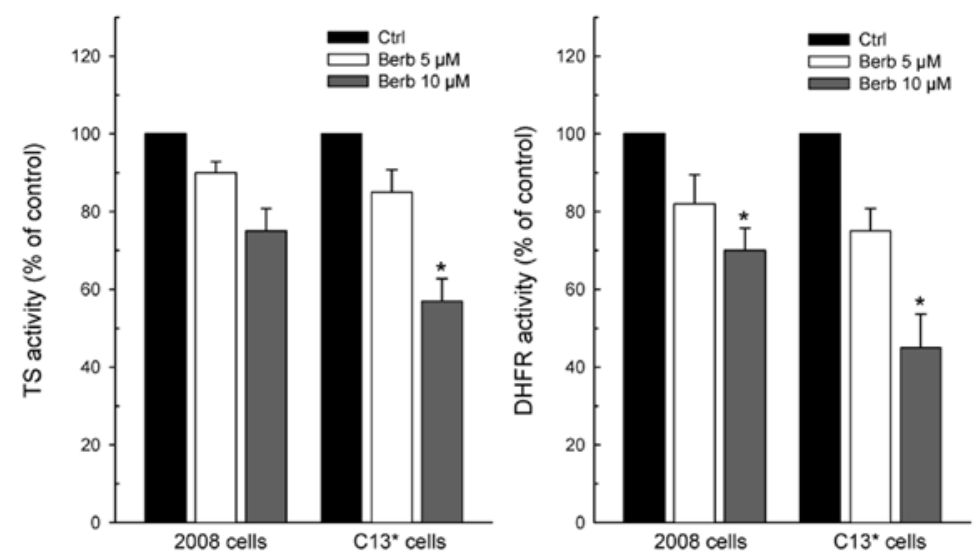

B
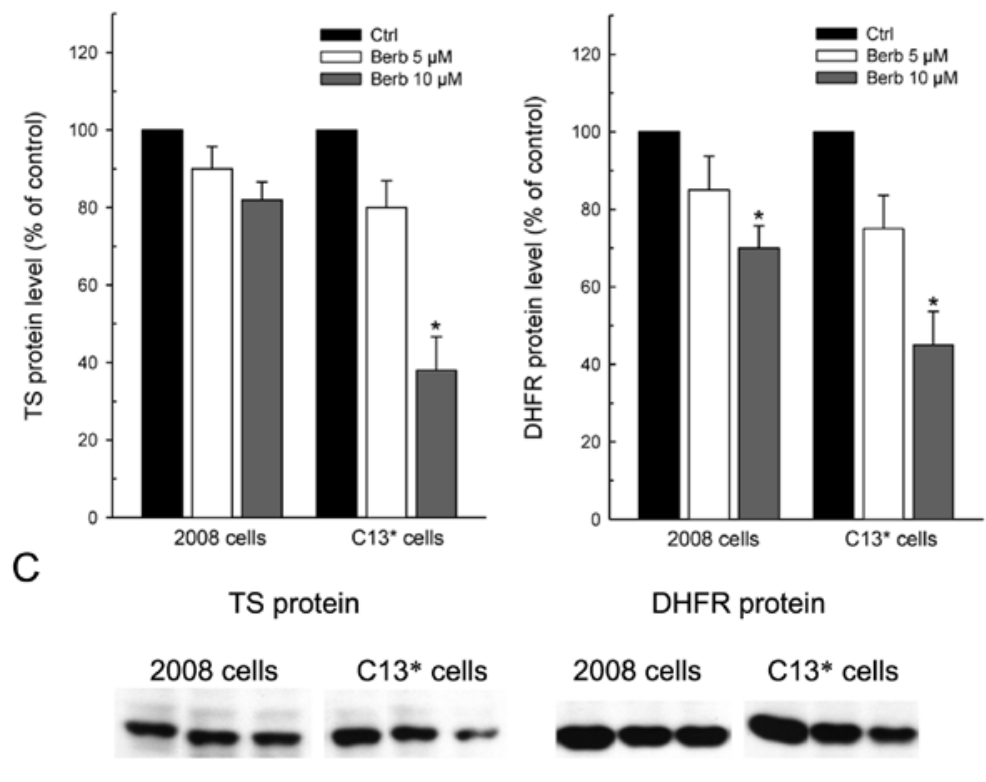

Berberine $\begin{array}{llllll}0 & 5 & 10 \mu \mathrm{M} & 0 & 5 & 10 \mu \mathrm{M}\end{array}$

$\begin{array}{llllll}0 & 5 & 10 \mu \mathrm{M} & 0 & 5 & 10 \mu \mathrm{M}\end{array}$

Figure 3. Effect of berberine on TS and DHFR expression in 2008 and C13* cells. (A) TS and DHFR activity and protein levels (B and C) were determined after a 72-h treatment with berberine 5 and $10 \mu \mathrm{M}$. hTS monomer, molecular mass 35 and hDHFR monomer, $21 \mathrm{kDa}$, were assayed in cell line extracts as described in Materials and methods. Equal lane loading was confirmed using a mouse anti-human $\beta$-tubulin antibody. The data taken from the densitometric scanning of the blots (C) were also graphed to better compare the differences of protein levels in the two cell lines (B). Results plotted represent the mean of three separate experiments performed in duplicate. Error bars, SEM. ${ }^{*} \mathrm{P}<0.05$; as determined by Student's t-test vs control.

This feature along with the comparison between the efficacy of berberine and that of the two well-known anticancer drugs, cDDP and 5-FU, towards the three cell lines is displayed in Fig. 2B. As is evident, berberine is the least effective of the three drugs against the parental line, but the most active towards the resistant one. Noteworthy, the $50 \%$ growth reduction of Vero cells was not reached even with $40 \mu \mathrm{M}$ berberine, but already with $10 \mu \mathrm{M}$ cDDP and $4.8 \mu \mathrm{M} 5-\mathrm{FU}$, indicating that berberine is more selective than the traditional chemotherapeutic compounds.

Modulation of TS and DHFR expression by berberine. We have previously reported that the cDDP-resistant human ovarian cancer cell line $\mathrm{C} 13^{*}$ showed collateral sensitivity towards two quinoxalinic compounds, new molecules designed as folate cycle enzyme inhibitors and structurally unrelated to the clas- sical pteridine-like compounds and that this effect was related to folate cycle enzyme impairment (44). The resemblance of berberine effects with those of the two quinoxalines prompted us to evaluate and compare the effects of berberine on TS and DHFR expression in this acquired cDDP-resistant line and its parental line 2008 .

It is interesting to note that, unlike traditional folate cycle inhibitors such as 5-FU, the cytotoxicity of berberine was accompanied by a greater inhibition of TS and DHFR expression in cell extracts from resistant cells than from sensitive ones. Therefore, the data reported in Fig. 3 explain, at least partly, the collateral sensitivity showed by $\mathrm{C} 13^{*}$ cells to berberine, since both TS and DHFR activities were decreased more in $\mathrm{C} 3^{*}$ than in 2008 cells by increasing drug concentrations (Fig. 3A). TS activity was reduced at $10 \mu \mathrm{M}$ berberine by 30 and $45 \%$ of the controls in 2008 and $C 13^{*}$ cells, respec- 
A
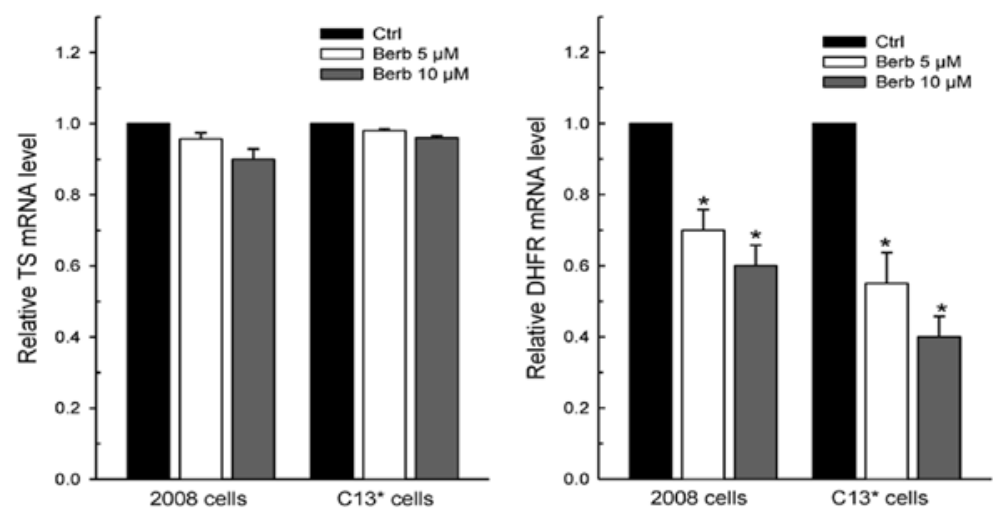

B
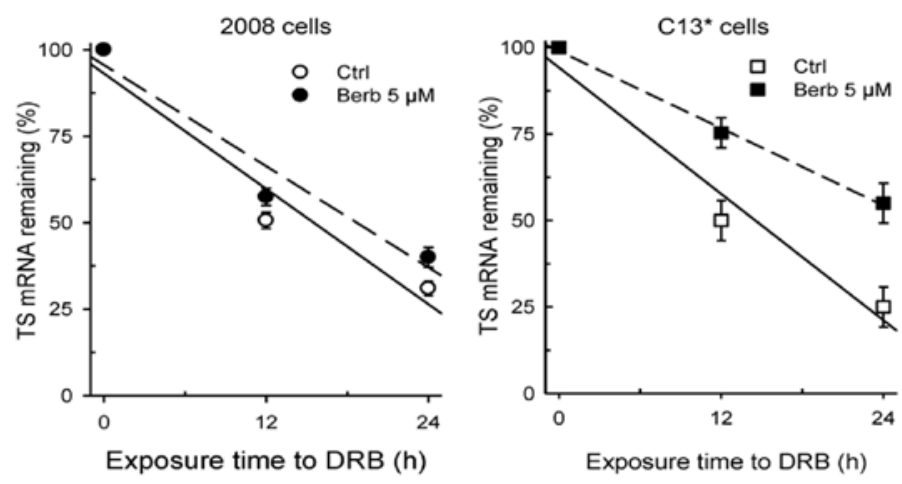

C
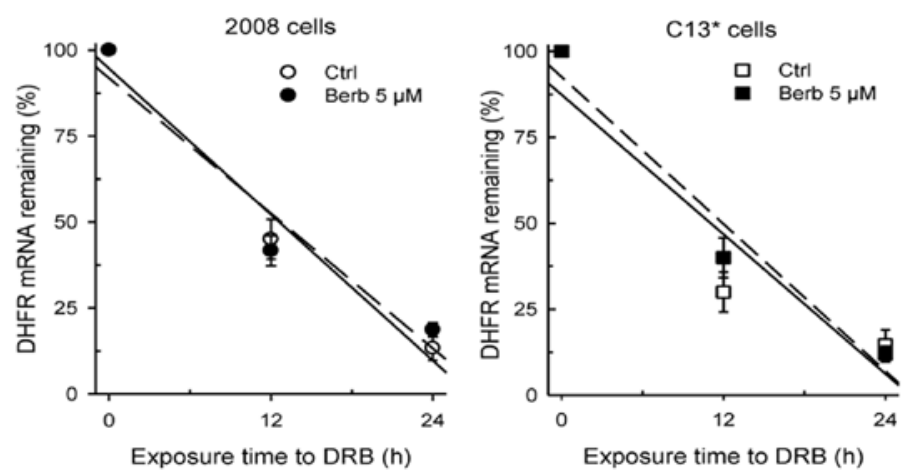

Figure 4. Effects of berberine on TS and DHFR transcripts. (A) Dose-response effect of berberine on TS and DHFR mRNA expression in 2008 and C13* cells. RT-PCR analysis was performed in 2008 and $\mathrm{C} 3^{*}$ cells treated for $72 \mathrm{~h}$ with the indicated concentration of the compound. The amount of TS mRNA was normalised to glyceraldehyde-3-phosphate dehydrogenase mRNA. Results represent the mean of three separate experiments performed in duplicate. Error bars, SEM. "P<0.05; as determined by Student's t-test vs control. The regression graphs of the kinetics of decay of TS mRNA (B) and DHFR mRNA (C) in 2008 and $\mathrm{C} 13^{*}$ cells pretreated for $72 \mathrm{~h}$ with berberine and then cotreated with the transcription inhibitor DRB (dichlorobenzimidazole riboside) $25 \mu \mathrm{g} / \mathrm{ml}$ for the times indicated. GAPDH mRNA levels also decreased with time (not shown). These blots are representative of findings from two experiments. Error bars, SEM.

tively; whereas, the residual DHFR activity after treatment was 70 and $45 \%$ of the respective controls.

This differential decrease of the enzyme activities reflected well the levels of both TS and DHFR proteins, which were both more downregulated in cDDP-resistant than in the sensitive cells (Fig. 3B and C).

Notably, again unlike 5-FU (44), berberine reduced the level of TS monomeric form without inducing ternary complex formation, which is considered a mechanism of resistance to 5-FU (45). Data from densitometric scanning indicated that residual TS protein levels were $\sim 80$ and $40 \%$ of control after treatment with the higher concentration of berberine in cDDPsensitive and in -resistant cells, respectively. Even DHFR protein was reduced by 30 and $55 \%$ in 2008 and $\mathrm{C}^{*} 3^{*}$ cells when compared to the respective controls.

Surprisingly, RT-PCR analysis revealed that only DHFR protein levels correlated with the respective decrease of DHFR mRNA amount, again more pronounced in the resistant line. In particular, the remaining DHFR mRNAs in 2008 cells were $70-80 \%$ of controls after treatment, while being $50-40 \%$ of control C13* cells. On the contrary, TS transcript was not significantly affected by drug exposure in either cell line (Fig. 4A).

To clarify whether the failure in impairing TS mRNA levels and the observed small difference between sensitive and resistant lines was also due to an effect of the drug on the turn- 
A

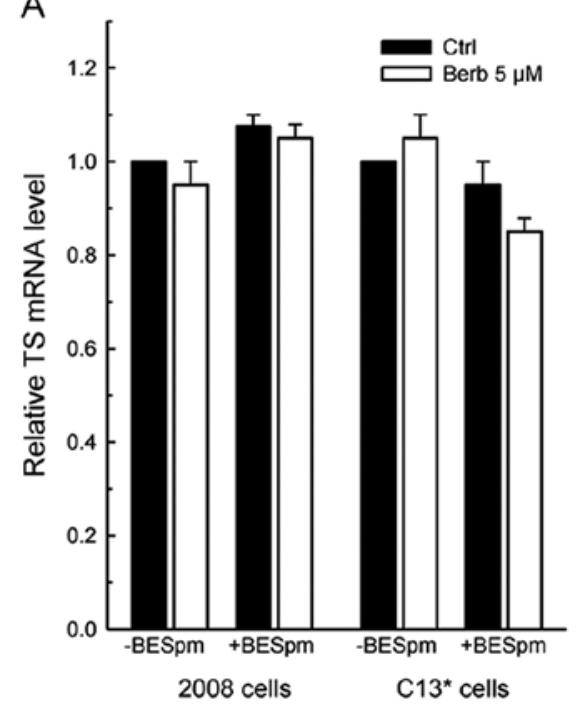

B

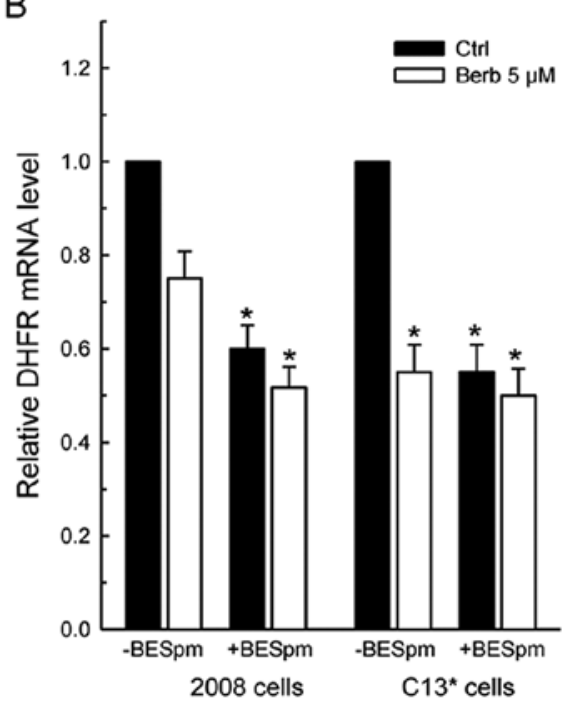

Figure 5. RT-PCR analysis of TS and DHFR mRNA levels after berberine and BESpm exposure. Cells (2008 and C13*) were treated for $72 \mathrm{~h}$ with $5 \mu \mathrm{M}$ berberine in the presence or absence of $10 \mu \mathrm{M}$ BESpm. The amount of TS mRNA (A) and DHFR mRNA (B) were normalised to glyceraldehyde-3-phosphate dehydrogenase mRNA. Results represent the mean of three separate experiments performed in duplicate. Error bars, SEM. $\mathrm{P}<0.05$; as determined by Student's t-test vs control.

over of TS mRNA transcripts, we compared the half-life of TS and DHFR messengers in the two cell lines pretreated with berberine $5 \mu \mathrm{M}$ for $72 \mathrm{~h}$ and then co-treated with the transcription inhibitor dichlorobenzimidazole riboside (DRB) to shut off transcription. The rates of mRNA decay were then monitored over a 24-h period. The data reported in Fig. $4 \mathrm{~B}$ and $\mathrm{C}$ indicate that there is no difference in both basal TS mRNA and DHFR mRNA stability between sensitive and resistant cells. However, as is evident from the regression plots of Fig. 4B, treatment with berberine caused a remarkable slowing of the TS mRNA degradation rate in $\mathrm{C} 13^{*}$ cells, which turned over at a rate almost twice lower than that in sensitive cells. As a result, TS mRNA stability increased to a lesser extent in 2008 cells from a half-life of $14.5 \mathrm{~h}$ in controls to $18.3 \mathrm{~h}$ in berberine-treated cells, but to a much greater extent in the resistant line, from a half-life of 14.2 to $23.8 \mathrm{~h}$, respectively. On the other hand, the rate of DHFR mRNA degradation was not affected by berberine in either cell line as the percentage of the remaining messengers was similar to the controls after drug exposure (Fig. 4C).

Noteworthy, in these conditions, berberine affected the cellular uptake of folic acid from culture medium (Table I). In particular, $10 \mu \mathrm{M}$ berberine reduced the accumulation of $50 \mathrm{nM}\left[{ }^{3} \mathrm{H}\right]$ folic acid by $\sim 13.3$ and $27.6 \%$ in 2008 and C13* cells, respectively (from $163.3 \pm 4$ to $141.4 \pm 7$ fmoles/mg of protein in 2008 cells and from $182.8 \pm 9$ to $132.9 \pm 11$ fmoles/ mg of protein in $\mathrm{C} 13^{*}$ cells; $\mathrm{n}=3$ ). Again, this differential effect correlates with the collateral sensitivity to berberine showed by the latter line.

Modulation of folate cycle enzymes and SSAT by combining berberine and Spm analogue. We have previously shown that these resistant cells are less responsive than their cDDP-sensitive counterparts the 2008 cells, to both the spermine analogue N1,N12-bisethylspermine (BESpm) (46) and the traditional anti-folates (44), when administered
Table I. Effect of berberine and BESpm on the uptake of $\left[{ }^{3} \mathrm{H}\right]$ folic acid in 2008 and $\mathrm{C} 13^{*}$ cells.

\begin{tabular}{lccccc}
\hline & \multicolumn{2}{c}{2008 cells } & & \multicolumn{2}{c}{ C13* cells } \\
\cline { 2 - 3 } \cline { 5 - 6 } Drugs & fmoles/mg prot & $(\%)$ & & fmoles/mg prot & $(\%)$ \\
\hline Ctrl & $163.3 \pm 4$ & 100 & $182.8 \pm 9$ & 100 \\
Berberine & $141.4 \pm 7$ & 86.59 & $132.9 \pm 11$ & 72.70 \\
$10 \mu \mathrm{M}$ & & & & \\
BESpm & $135.2 \pm 15$ & 82.79 & $139.15 \pm 8$ & 76.12 \\
$10 \mu \mathrm{M}$ & & & & \\
\hline
\end{tabular}

alone. Therefore, we also evaluated the effects of berberine combined with the polyamine analogue in the human ovarian cDDP-resistant $\mathrm{C} 13^{*}$ cells.

RT-PCR analysis revealed that $10 \mu \mathrm{M}$ BESpm, concentration chosen from the previously reported dose-response studies (32) and berberine did not significantly affect the TS mRNA levels in either cell line (Fig. 5A). However, both drugs decreased the level of DHFR mRNA in the cell lines, again particularly in resistant cells, but without potentiated effects when combined (Fig. 5B).

Similarly to berberine, the modulation of folate cycle enzymes by BESpm seems partly ascribable to the reduced folate uptake in the cell lines. As reported in Table I, $10 \mu \mathrm{M}$ BESpm reduced the accumulation of $50 \mathrm{nM}\left[{ }^{3} \mathrm{H}\right]$ folic acid by $\sim 17$ and $24 \%$ in 2008 and $\mathrm{C} 13^{*}$ cells, respectively (from $163.3 \pm 4$ to $135.2 \pm 15$ fmoles $/ \mathrm{mg}$ of protein in 2008 cells and from $182.8 \pm 9$ to $139.15 \pm 8$ fmoles/mg of protein in $\mathrm{C}^{*} 3^{*}$ cells; $\mathrm{n}=3$ ).

The effect on SSAT expression was evident. Fig. 6A shows that SSAT mRNA level was almost tripled and doubled by berberine in 2008 and $\mathrm{C} 13^{*}$ cells, respectively, reaching the 
A

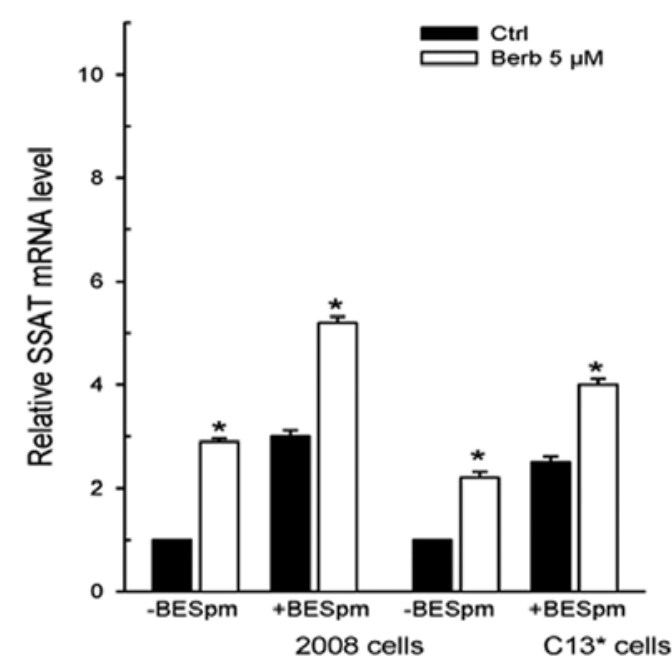

B

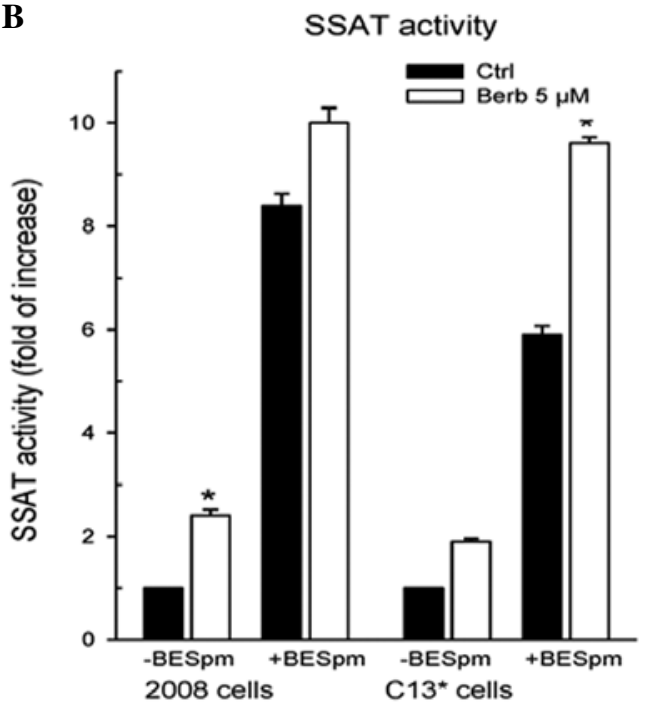

Figure 6. Effects of berberine and BESpm on SSAT expression. SSAT mRNA level by RT-PCR (A) and SSAT activity by radioactive assay (B) were performed in 2008 and $\mathrm{C}^{*} 3^{*}$ cells treated for $72 \mathrm{~h}$ with $5 \mu \mathrm{M}$ berberine in the presence or absence of $10 \mu \mathrm{M}$ BESpm. The amount of SSAT mRNA was normalised to glyceraldehyde-3-phosphate dehydrogenase mRNA. Results represent the mean of three separate experiments performed in duplicate. Error bars, SEM. "P<0.05; as determined by Student's t-test vs control.

A

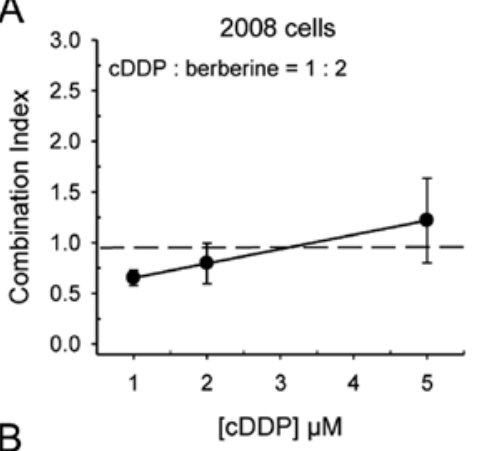

B

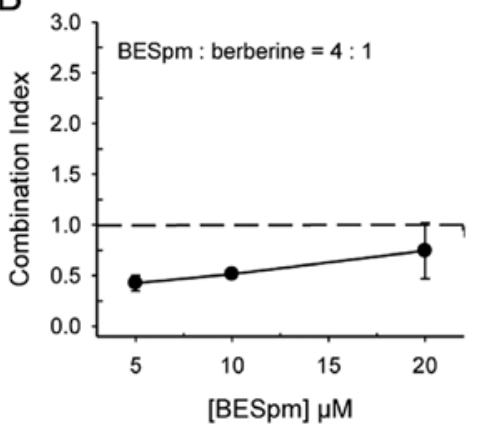

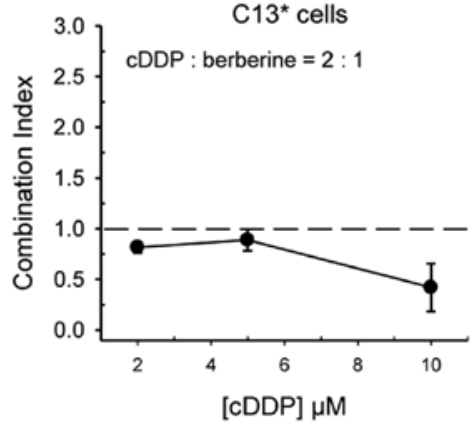

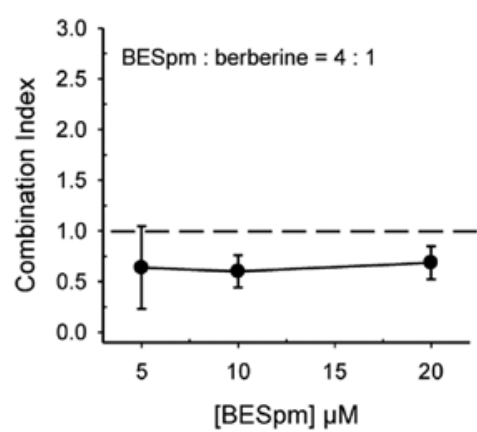

Figure 7. Median-effect analysis of drug combinations at the proper constant ratios. Cells (2008) (left panels) and the C13* (right panels) were allowed to attach overnight and then simultaneously treated with berberine and with the indicated concentrations of cDDP (A) or BESpm (B) in 24-well plates. Following a 3-day exposure, cells were stained with crystal violet. Results are expressed as combination indexes (CIs), where CIs $<1$ indicate synergistic effects, CIs $>1$ indicate antagonistic effects, CIs=1 indicate additivity. Results represent the mean of three separate experiments performed in duplicate. Error bars, SEM.

same induction caused by BESpm. Notably, berberine alone increased SSAT expression by itself but even more interestingly, stimulated the SSAT overexpression by the polyamine analogue. In fact, when combined, berberine increased by 2- and 1.5-fold SSAT mRNA level induced by BESpm in sensitive and resistant cells, respectively. As a consequence, SSAT activity was increased by berberine alone in both cell lines, but the drug over-induced the enzyme activity by the analogue additively in sensitive cells and synergistically in resistant cells (Fig. 6B).

Therefore, despite SSAT expression being less inducible by the analogue in the $\mathrm{C} 13^{*}$ resistant cells compared to sensitive 2008 cells (46), in the presence of berberine, the reduced SSAT activity in the resistant line was reverted to induction level of the enzyme in sensitive cells by the co-treatment of berberine with Spm analogue. 
Effects on cell growth by combining berberine with cDDP or with BESpm. Previous studies have shown that berberine potentiated the chemotherapeutic effect of cDDP by enhancing apoptosis in HeLa cells (10). Accordingly, we have ascertained the nature of the combination of berberine with cDDP, combined simultaneously in our cDDP-sensitive and -resistant cell model, determined by median-effect analysis. Cells were exposed to each drug alone and to their combinations at constant ratio, deduced from $\mathrm{IC}_{50}$ values. The survival data were then plugged into the software CalcuSyn ver. 2.0 (Biosoft), which provides the combination index (CI) for each level of cell kill. As depicted in Fig. 7A, the combination of cDDP and berberine resulted in mostly supra-additive effects in 2008 cells and mostly synergistic in $\mathrm{C} 3^{*}$ cells, confirming that berberine may facilitate cDDP activity, even in resistant cells.

We have also ascertained the nature of the combination of berberine with BESpm, combined simultaneously at a fixed ratio. As expected from the data of the modulation of the folate cycle enzymes and of the stimulated induction of SSAT expression, berberine synergistically increased cell growth inhibition by BESpm in both cell lines, even in resistant cells. Fig. 7B shows that berberine and Spm analogue combination is almost as effective in sensitive 2008 cells as in resistant $\mathrm{C}^{2} 3^{*}$ cells, producing synergistic cell killing in both lines.

\section{Discussion}

The natural isoquinoline berberine has shown antiproliferative activity against a variety of human cancer cells $(14,15)$ and it has also been suggested as an anticancer drug for the treatment of ovarian cancer since it was shown to inhibit the proliferation of human ovarian tumor SVKO3 cells (47).

We show for the first time, that despite the cytotoxicity of berberine against a human ovarian cell line it is lower than that of the traditional anticancer drugs such as CDDP and 5-FU, the isoquinoline is more effective than the chemotherapeutic agents against the derived cDDP-resistant counterpart, C13* cells, which is even more sensitive to the alkaloid than parental cells, displaying collateral sensitivity. Besides, the natural compound was also more selective, showing scant toxicity towards non-tumorigenic Vero lineage.

Even if other mechanisms cannot be ruled out, the collateral sensitivity seems to correlate, at least partly, with the higher downregulation of TS and DHFR in C13* cells compared to 2008 cells. These effects are more relevant since this resistant line showed elevated expression of the folate cycle enzymes, thymidylate synthase (TS) and dihydrofolate reductase (DHFR), due to cisplatin-resistance phenotype (2).

The modulation of folate cycle enzyme expression and the cytotoxicity may be explained by the ability of berberine to bind nucleic acids. The binding of berberine to DNA and RNA has been defined sufficiently efficient and very similar to ethidium bromide to justify its use in spectrofluorimetric determination of the nucleic acids (48).

The anticancer activity of berberine appears to derive from its ability to form strong complexes with adenine-thymine base pair specific regions of nucleic acids, induce DNA damage and exert related effects such as telomerase inhibition, topoisomerase poisoning and inhibition of gene transcription (49-51).
The antiproliferative activity was also recently ascribed to its ability to bind specifically to oligonucleotides and to stabilize DNA triplexes or G-quadruplexes via telomerase and topoisomerase inhibition $(52,53)$. A non-classical intercalation model for berberine DNA binding has been confirmed (54). Very recently, substitution at the 13-position with unprecedented phenylalkyl groups remarkably enhanced the DNA binding action of berberine, providing insights into the importance of the 13-position substitution of berberine. This may be useful for the design and development of berberine structurally related new drugs with more specific and higher efficacy (55).

It has been reported that DNA intercalating agents and DNA minor groove-binders also bind to TS mRNA site 1 construct (56). Moreover, we have also recently shown that the antibiotic distamycin, which binds at the relatively narrow AT-rich sequences of the minor groove of double-strand DNA $(23,24)$, affects the expression of folate cycle enzymes even at the cellular level; this minor groove binder is able to modulate TS mRNA in vivo, thus affecting the translation and enzyme activity (22).

Similarly, berberine was shown to bind preferentially to AT rich sequences in DNA (57), also present in TS mRNA, thus accounting for the effect on folate enzymes expression and consequently on cytotoxicity.

Berberine binding to DNA probably also affects TS and DHFR gene transcription, but post-transcriptional effects such as stabilization affects TS mRNA levels rather than DHFR mRNA levels, suggesting a preferential binding to the former mRNA rather than the latter. In addition, the post-transcriptional stabilization of TS mRNA in $\mathrm{C} 13^{*}$ cells, more than in 2008 cells, may indicate differences in transcript structures affecting berberine binding and/or differential resistance to mRNA catabolic enzymes between sensitive and resistant cells. However, in our experiments, berberine modulated the expression of TS and DHFR both at transcriptional and posttranscriptional level, since DHFR mRNA level decreased more in $\mathrm{C}_{13}{ }^{*}$ cells than in 2008 cells, whereas TS mRNA levels were almost not affected by berberine in the cell lines. Nevertheless, the final protein levels of the two enzymes and their activities were almost equally affected, but in particular in resistant cells. Therefore, TS expression appears to be the more differentially modulated by the alkaloid, as a lack of effect at transcriptional level was displayed both in sensitive and in resistant cells, along with a significantly reduced TS mRNA turnover only in $\mathrm{C} 13^{*}$ cells. Of note, the impairment of the folate cycle also seems partly ascribable to a reduction of folic acid accumulation in both cell lines. In particular, the resistant cells treated with berberine accumulate less folic acid than sensitive cells when compared to the respective untreated controls. Folate is a member of vitamin B family and plays an essential role in cell survival by participating in the biosynthesis of nucleic and amino acids. Again, the slightly more compromised accumulation of this parent compound of purine and pyrimidine bases and amino acids contributes to explain the reduced tolerance to the isoquinoline alkaloid of the $\mathrm{C} 13^{*}$ cells.

DNA binding ligands, including minor groove binders such as distamycin and intercalators are considered amplifiers of the DNA damaging effects of anticancer drugs (58). 
Therefore, as distamycin synergistically enhanced cDDP cell killing (22), similarly, it is likely that berberine potentiated the action of cDDP, as evidenced by the fraction affected of the cells killed in synergy studies, by means of the downregulation of TS and DHFR expression, thus preventing the new synthesis of damaged DNA. This mechanism is also supported by the reduced accumulation of folic acid, particularly in the resistant cells.

The upregulation of folate cycle enzymes in ovarian carcinoma cells (6), including this cDDP-resistant line (44) and the deficient SSAT expression previously reported (46) represent mechanisms of reduced sensitivity to better survive the cell inhibition caused by antifolates such as 5-FU and by polyamine depleting drugs, such as Spm analogues, but also the drug injury brought about by the alkylating agents such as cDDP. Therefore, our efforts were aimed to potentiate cDDP cytotoxicity even in cDDP-resistant cells by targeting the folate cycle and the polyamine metabolism, which have been shown to interrelate $(27,28)$. Our group reported previously a synergistic increase in SSAT mRNA levels and cell death in response to the combination with novel TS inhibitors and SSAT inducers (29).

We report now, that the combination of berberine and the Spm-analogue BESpm modulates folate cycle enzymes, as reflected in the reduction of DHFR mRNAs in particular; whereas TS mRNAs were affected only to a lesser extent and in resistant cells, confirming that interrelations exist between these two metabolic pathways in this cell model. The data reported suggest that the synergistic inhibition of cell growth by berberine and BESpm combination involves DHFR gene downregulation more than TS gene, again mainly in resistant cells. This effect is accompanied by the induction of SSAT activity in the cell lines. However, the effect of this drug combination in sensitive cells seems to be mediated by the induction of polyamine catabolism rather than by folate cycle modulation, whereas, in resistant cells both metabolisms are more affected.

It is almost consolidated evidence that when both the folate cycle and the polyamine metabolism are concurrently modulated, cancer cell growth from different tumor types may be more validly treated. In particular, the combination of classical or novel inhibitors of TS and DHFR with inducing agents of the key catabolic enzyme of polyamine catabolism, SSAT, such as DENSpm or BESpm has proven therapeutic efficacy against tumor cell lines (27-29).

Accordingly, our results show that the co-treatment with berberine and BESpm, which caused DHFR downregulation and SSAT induction, resulted in a synergic cell killing in both lines, reverting the sensitization of resistant cells to the Spm analogue to the level of the sensitive counterpart. This evidence, correlating with the synergic induction of SSAT activity by drug combination is particularly important in resistant cells, since the cDDP-resistance phenotype conferred defective basal SSAT expression in $\mathrm{C}^{2} 3^{*}$ cells in comparison to parental 2008 cells and thus a reduced sensitivity to the induction of SSAT activity and cell growth inhibition by the polyamine analogues $(29,46)$.

The consequent polyamine depletion caused by SSAT induction by berberine and BESpm combination may facilitate DNA intercalation by berberine, along with decreased
DNA aggregation leading to relaxation of chromatin structure (59). This may favour the interaction and the effects of the analogue with DNA, partly accounting for the enhanced cytotoxicity of the combinations. In addition, the enhanced induction of polyamine catabolism leads to increased acetylated Spm or Spd concentration and to elevation of reactive oxygen species $(29,60)$, which correlating with Spm depletion, may initiate the apoptotic cascade and account for synergistic interactions.

Moreover, decarboxylated S-adenosylmethionine (SAM) is an essential precursor in the formation of both spermidine and spermine. SAM is formed from methionine through the addition of adenosine. Because 5-methyltetrahydrofolate donates a methyl group to homocysteine to produce methionine, folate deficiency may decrease polyamine synthesis (61). Therefore, BESpm may cause polyamine depletion both by the wellknown direct action on the enzymes of polyamine metabolism and by reducing folate uptake by cells, particularly by resistant ones.

In conclusion, our data show for the first time that a cDDP-resistant and polyamine analogue cross-resistant cell line is more sensitive to berberine than the parental cell line. This collateral sensitivity is partly attributable to a more pronounced downregulation of folate cycle enzymes in cDDPresistant than in the sensitive cells. These data also show that berberine is more effective against resistant cells than cDDP or 5-FU and even more selective than the traditional anticancer drugs. Besides, we demonstrate that the natural compound berberine enhances the cell growth inhibition caused by cDDP and confirm the interrelationship between folate cycle and polyamine metabolism, since SSAT expression was upregulated by the combination of berberine and an Spm analogue, accounting for the observed synergistic cell killing.

\section{Acknowledgements}

This study was supported by EU LIGHTS (LIGands to interfere with Human Thymidylate Synthase) project of the 6th Framework Program, LSHCCT-2006-037852 and AIRC IG 10474 to M.P. Costi. This study was also supported by Associazione Angela Serra per la Ricerca sul Cancro, Azienda Ospedaliera Policlinico di Modena, Modena, Italy.

\section{References}

1. Ozols RF, Bookman MA, Connolly DC, et al: Focus on 433 epithelial ovarian cancer. Cancer Cell 5: 19-24, 2004.

2. Muggia F: Platinum compounds 30 years after the introduction of cisplatin: implications for the treatment of ovarian cancer. Gynecol Oncol 112: 275-281, 2009.

3. Jakubowicz-Gil J, Paduch R, Piersual T, Glowniak K, Gawron A and Kandefer M: The effect of quercetin on pro-apoptotic activity of cisplatin in HeLa cells. Biochem Pharmacol 6: 1343-1350, 2005.

4. Maeda H, Hori S, Ohizumi H, Segawa T, Kakehi Y, Ogawa O and Kakizuka A: Effective treatment of advanced solid tumors by the combination of arsenic trioxide and L-buthionine-sulfoximine. Cell Death Differ 11: 737-746, 2004.

5. Umanzor J, Aguiluz M, Pineda C andrade S, Erazo M, Flores C and Santillana S: Concurrent cisplatin/gemcitabine chemotherapy along with radiotherapy in locally advanced cervical carcinoma: a phase II trial. Gynecol Oncol 100: 70-75, 2006.

6. Scanlon KJ and Kashani-Sabet M: Elevated expression of thymidylate synthase cycle genes in cisplatin-resistant human ovarian carcinoma A2780 cells. Proc Natl Acad Sci USA 85: 650-653, 1988. 
7. Wysocki PJ: Targeted therapy of hepatocellular cancer. Expert Opin Investig Drugs 19: 265-274, 2010.

8. Lin CC, Yang JS, Chen JT, et al: Berberine induces apoptosis in human HSC-3 oral cancer cells via simultaneous activation of the death receptor-mediated and mitochondrial pathway. Anticancer Res 27: 3371-3378, 2007.

9. Mantena SK, Sharma SD and Katiyar SK: Berberine, a natural product, induces G1-phase cell cycle arrest and caspase-3-dependent apoptosis in human prostate carcinoma cells. Mol Cancer Ther 5: 296-308, 2006.

10. Yoon MJ, So HS, Cho HJ, et al: Berberine, a natural product, combined with cisplatin enhanced apoptosis through a mitochondria/caspase-mediated pathway in HeLa cells. Biol Pharm Bull 31: 789-795, 2008

11. Yi ZB, Yan Y, Liang YZ, et al: Evaluation of the antimicrobial mode of berberine by LC/ESI-MS combined with principal component analysis. J Pharm Biomed Anal 44: 301-304, 2007.

12. Liu JC, Chan P, Chen YJ, et al: The antihypertensive effect of the berberine derivative 6-protoberberine in spontaneously hypertensive rats. Pharmacology 59: 283-289, 1999.

13. Kuo CL, Chi CW and Liu TY: The anti-inflammatory potential of berberine in vitro and in vivo. Cancer Lett 203: 127-137, 2004.

14. Un Y, Xun K, Wang Y, et al: A systematic review of the anticancer properties of berberine, a natural product from Chinese herbs. Anticancer Drugs 20: 757-769, 2009.

15. Tang J, Feng Y, Tsao S, et al: Berberine and Coptidis rhizoma as novel antineoplastic agents: a review of traditional use and biomedical investigations. J Ethnopharmacol 126: 517, 2009.

16. Kong B, Huang S, Wang W, May D, et al: Arsenic trioxide induces apoptosis in cisplatin-sensitive and -resistant ovarian cancer cell lines. Int J Gynecol Cancer 15: 872-877, 2005

17. Lin JP, Yang JS, Lee JH, Hsieh WT and Chung JG: Berberine induces cell cycle arrest and apoptosis in human gastric carcinoma SNU-5 cell line. World J Gastroenterol 12: 21-28, 2006.

18. Halestrap AP, Doran E, Gillespie JP and O'Toole A: Mitochondria and cell death. Biochem Soc Trans 28: 170-171, 2000.

19. Duverger V, Sartorius U, Klein-Bauernschmitt P, Krammer PH and Schlehofer JR: Enhancement of cisplatin-induced apoptosis by infection with adeno-associated virus type 2 . Int J Cancer 97: 706-712, 2002

20. Li JJ, Tang Q, Li Y, Hu BR, Ming ZY, Fu Q, Qian JQ and Xiang JZ: Role of oxidative stress in the apoptosis of hepatocellular carcinoma induced by combination of arsenic trioxide and ascorbic acid. Acta Pharmacol Sin 27: 1078-1084, 2006.

21. Jantova S, Cipak L and Letasiova S: Berberine induces apoptosis through a mitochondrial/caspase pathway in human promonocytic U937 cells. Toxicol In Vitro 21: 25-31, 2007.

22. Marverti G, Guaitoli G, Ligabue A, Frassineti C, Monti MG, Lombardi P and Costi MP: Distamycin A and derivatives as synergic drugs in cisplatin-sensitive and -resistant ovarian cancer cells. Amino Acids 42: 641-653, 2012

23. Arcamone F, Pencos PG, Orezzi PG, Nicolella V and Pirelli AM: Structure and synthesis of distamycin A. Nature 203: 1064-1065, 1964.

24. Abu-Daya A and Fox KR: Interaction of minor groove binding ligands with long AT tracts. Nucleic Acids Res 25: 4962-4969, 1997.

25. Carreras CW and Santi DV: The catalytic mechanism and structure of thymidylate synthase. Annu Rev Biochem 64 721-762, 1995

26. Costi $\mathrm{P}$ and Ferrari S: Update on antifolate drugs targets. Curr Drug Targets 2: 135-166, 2001

27. Choi W, Gerner EW, Ramdas L, et al: Combination of 5-fluorouracil and N1,N11-Diethylnorspermine markedly activates spermidine/spermine N1-acetyltransferase expression, depletes polyamines and synergistically induces apoptosis in colon carcinoma cells. J Biol Chem 280: 3295-3304, 2005.

28. Allen WL, McLean EG, Boyer J, et al: The role of spermidine/ spermine N1-acetyltransferase in determining response to chemotherapeutic agents in colorectal cancer cells. Mol Cancer Ther 6: 128-137, 2007.

29. Marverti G, Ligabue A, Guerrieri D, et al: Spermidine/spermine N1-acetyltranferase modulation by novel folate cycle inhibitors in cisplatin-sensitive and -resistant human ovarian cancer cell lines. Gynecol Oncol 117: 202-210, 2010.

30. Wallace HM and Niiranen K: Polyamine analogues - an update. Amino Acids 33: 261-265, 2007

31. Wallace HM and Fraser AV: Inhibitors of polyamine metabolism: review article. Amino Acids 26: 353-365, 2004.
32. Marverti G, Monti MG, Pegg AE, et al: Spermidine/spermine N1-acetyltransferase transient over-expression restores sensitivity of resistant human ovarian cancer cells to N1,N12bis(ethyl)spermine and to cisplatin. Carcinogenesis 26 1677-1686, 2005

33. Andrews PA, Murphy MP and Howell SB: Differential potentiation of alkylating and platinating agent cytotoxicity in human ovarian carcinoma cells by glutathione depletion. Cancer Res 45 6250-6253, 1985

34. Rossi T, Coppi A, Bruni E, Ruberto A, Santachiara S and Baggio G: Effects of anti-malarial drugs on MCF-7 and Vero cell replication. Anticancer Res 27: 2555-2560, 2007.

35. Lowry OH, Rosebrough NJ, Farr AL and Randall RJ: Protein measurement with the Folic phenol reagent. J Biol Chem 193: 265-275, 1951.

36. Kueng W, Siber E and Eppenberger U: Quantification of cells cultured on 96-well plates. Anal Biochem 182: 16-19, 1989.

37. van Triest B, Pinedo HM, van Hensbergen Y, et al: Thymidylate synthase level as the main predictive parameter for sensitivity to 5-fluorouracil, but not for folate-based thymidilate synthase inhibitors, in 13 nonselected colon cancer cell lines. Clin Cancer Res 5: 643-654, 1999.

38. Rothenberg SP, Perwaiz Iqbal $M$ and Da Costa M: A simplified radioenzymatic assay for dihydrofolate reductase using $\left[{ }^{3} \mathrm{H}\right]$ dihydrofolate. Anal Biochem 103: 152-156, 1980.

39. Bradford MM: A rapid and sensitive method for quantification of microgram quantities of protein utilising the principle of proteindye binding. Anal Biochem 72: 248-254, 1976.

40. Arocho A, Chen B, Ladanyi M and Pan Q: Validation of the $2^{-\Delta \Delta C}$ calculation as an alternate method of data analysis for quantitative PCR of BCR-ABL P210 transcripts. Diagn Mol Pathol 15: 56-61, 2006.

41. Kansara V, Paturi D, Luo S, Gaudana R and Mitra AK: Folic acid transport via high affinity carrier-mediated system in human retinoblastoma cells. Int J Pharm 355: 210-219, 2008.

42. CaseroRAJr, GabrielsonEW andPegg AE: Immunohistochemical staining of spermidine/spermine N1-acetyltransferase superinduced in response to treatment with antitumour polyamine analogues. Cancer Res 54: 3955-3958, 1994.

43. Chou TC and Talalay P: Quantitative analysis of dose-effect relationships: the combined effects of multiple drugs or enzyme inhibitors. In: Advances in Enzyme Regulation. Weber G (ed.) Pergamon Press, New York, NY, pp27-55, 1984.

44. Marverti G, Ligabue A, Paglietti G, et al: Collateral sensitivity to novel thymidylate synthase inhibitors correlates with folate cycle enzymes impairment in cisplatin-resistant human ovarian cancer cells. Eur J Pharmacol 615: 17-26, 2009.

45. Chu E and Allegra CJ: The role of thymidylate synthase as an RNA binding protein. Bioessays 18: 191-198, 1996

46. Marverti G, Piccinini G, Ghiaroni S, Barbieri D, Quaglino D and Moruzzi MS: N1,N12-bis(ethyl)spermine effect on growth of cisdiamminedichloroplatinum(II)-sensitive and -resistant human ovarian carcinoma cell lines. Int J Cancer 78: 33-40, 1998.

47. Orfila L, Rodriguez M, Colman T, Hasegawa M, Merentes E and Arvelo F: Structural modification of berberine alkaloids in relation to cytotoxic activity in vitro. $\mathrm{J}$ Ethnopharmacol 71: 449-456, 2000

48. Gong GQ, Zong ZX and Song YM: Spectrofluorometric determination of DNA and RNA with berberine. Spectrochimica Acta A Mol Biomol Spectrosc 55: 1903-1907, 1999.

49. Debnath D, Suresh Kumar G, Nandi R and Maiti M: Interaction of berberine chloride with deoxyribonucleic acids: evidence for base and sequence specificity. Indian J Biochem Biophys 26: 201-208, 1989

50. Bhadra K, Maiti M and Suresh Kumar G: Berberine-DNA complexation: new insights into the cooperative binding and energetic aspects. Biochim Biophys Acta 1780: 1054-1061, 2008

51. Tan W, Li Y, Chen M and Wang Y: Berberine hydrochloride: anticancer activity and nanoparticulate delivery system. Int J Nanomedicine 6: 1773-1777, 2011

52. Maiti M and Kumar GS: Polymorphic nucleic acid binding of bioactive isoquinoline alkaloids and their role in cancer. J Nucleic Acids 2010: 1-23, 2010.

53. Bhadra K and Kumar GS: Therapeutic potential of nucleic acidbinding isoquinoline alkaloids: binding aspects and implications for drug design. Med Res Rev 31: 821-862, 2011.

54. Ferraroni M, Bazzicalupi C, Bilia AR and Gratteri P: X-ray diffraction analyses of the natural isoquinoline alkaloids Berberine and Sanguinarine complexed with double helix DNA d(CGTACG). Chem Commun 47: 4917-4919, 2011. 
55. Bhowmik D, Hossain M, Buzzetti F, D'Auria R, Lombardi P and Kumar GS: Biophysical studies on the effect of the 13 position substitution of the anticancer alkaloid berberine on its DNA binding. J Phys Chem B 116: 2314-2324, 2012.

56. Cho J and Rando RR: Specific binding of Hoechst 33258 to site 1 thymidylate synthase mRNA. Nucleic Acids Res 28: 2158-2163, 2000.

57. Mazzini S, Bellucci MC and Mondelli R: Mode of binding of the cytotoxic alkaloid berberine with the double helix oligonucleotide d(AAGAATTCTT) ${ }_{2}$. Bioorg Med Chem 11: 505-514, 2003.

58. Hiraku Y, Oikawa S and Kawanishi S: Distamycin A, a minor groove binder, changes enediyne-induced DNA cleavage sites and enhances apoptosis. Nucleic Acids Res (Suppl) 2: 95-96, 2002.
59. Basu S, Feuerstein BG, Dennis FD, Lubich WP, Bergeron RJ, Samejima K and Marton LJ: Correlation between the effects of polyamine analogues on DNA conformation and cell growth. Cancer Res 49: 5591-5597, 1989.

60. Agostinelli E, Arancia G, Dalla Vedova L, Belli F, Marra M, Salvi $\mathrm{M}$ and Toninello A: The biological functions of polyamine oxidation products by amine oxidases: perspectives of clinical applications. Amino Acids 27: 347-358, 2004.

61. Sun D, Wollin A and Stephen AM: Moderate folate deficiency influences polyamine synthesis in rats. J Nutr 132: 2632-2637, 2002. 